\title{
MEMBANGUN IDENTITAS INKLUSIF \\ Krisis Identitas dalam Lensa Kajian Poskolonialisme
}

Robertus Wijanarko

\begin{abstract}
Multidimentional crisis which became more visible in the Covid-19 pademic era, actually rooted in the crisis of identity of Indonesia. It occurs, especially when identitys is considered as essential caracters or inherent features of this nation, inherited from the previous generation. The understanding of such kind of identity causes defensive, exclusive attitudes at the level of individual, communal, or even as a nation. In this perspective life is simply considered as an arena of contestation and will end up in the subordination of the others. By utilizing the lens of Postcolonial Theory, I axhibit the roots of that crisis of identity, and also propose a new perspective, which is comprehending identity as a production or a continuous process in a making. This new understanding of identity, I believe, will enable Indonesia to cope with the crisis, and to find ethical foundations in preserving and cultivating their life inclusively.
\end{abstract}

Keywords: crisis of identity, colonial residue, identity as a production.

\section{Abstrak}

Krisis multidimensi yang menjadi transparan di masa Pandemi Covid-19 berakar pada krisis identitas dari bangsa Indonesia. Terlebih ketika Identitas dipahami sebagai ciri-ciri hakiki yang selalu melekat dan diwarisi dari anakanak bangsa ini. Pemahaman identitas semacam ini berujung pada sikap individual, entitas komunal, dan bangsa yang defensif dan eksklusif. Kehidupan dialami sebagai medan kontestasi dan berjuangan untuk mensubordinasi yang lain. Melalui lensa kajian Poskolonial, penulis menunjukkan akar-akar krisis Identitas tersebut, dan mengusulkan perspektif baru, yakni memahami identitas sebagai proses produksi atau proses menjadi. 
Pemahaman baru tentang identitas ini, menurut hemat penulis, akan mampu membuat bangsa Indonesia mengelola krisis dengan baik, dengan tetap menemukan dasar-dasar etis dalam melestarikan dan mengembangkan hidupnya secara inklusif.

Kata kunci: krisis identitas, residu kolonialisme, identitas sebagai produksi.

Pandemi Covid-19 yang menguji daya tahan bangsa kita menyuguhkan potret konkret situasi bangsa dan negara kita secara lebih transparan. Kita bisa melihat dengan lebih jelas titik-titik lemah kita dalam berbangsa dan bernegara, sekaligus mengenali potensi-potensi yang masih terus perlu dirawat dan dikembangkan sebagai modal untuk terus berdiri tegak sebagai bangsa dan negara yang besar. Pertama-tama kita menyaksikan, krisis kesehatan yang kemudian bergulir ke krisis ekonomi, mengintensifikasi aneka krisis yang sebelumnya mulai muncul di beberapa sektor atau level kehidupan bangsa kita.

Maraknya politik identitas yang belum usai, pasca pemilihan kepala negara ataupun kepala daerah, yang mengawetkan potensi laten konflik sosial antara kelompok masyarakat, yang sepanjang sejarah bangsa ini selalu hadir secara sporadis, seolah menemukan energi baru seiring dengan suasana masyarakat yang lelah dan pengap akibat pandemi. Para pemain politik identitas memanfaatkan krisis sosial dan ekonomi untuk menegaskan eksistensi, dan mengartikulasikan sikap mereka dengan mengabaikan ongkos sosial yang ditimbulkannya. Anggapan bahwa negara-negara dengan sistem politik otoritarian (komunis) dianggap lebih mampu merespon gejolak sosial politik, menyusul pergolakan sosial politik semasa pandemi, dibandingkan dengan respon negara-negara dengan sistem demokrasi, tak kurang juga masuk menjadi tema perdebatan politik di negara kita. Apakah kita tengah tidak terjebak dalam sistem politik demokrasi liberal yang ternyata dianggap gagal itu, dan kurang berhasil membangun tata politik berdasar demokrasi Pancasila? Dalam perhelatan dan kontestasi paham politik semacam ini, wacana untuk melirik sistem negara berorientasi tradisi agama tertentu, tentu saja juga mengemuka. 
Selain itu krisis kesehatan yang mengemuka menyusul pandemi menguak betapa sistem jaminan kesehatan dan jejaring layanan kesehatan, serta kesenjangan akses ke fasilitas kesehatan menjadi problem kompleks yang masih terus dialami oleh bangsa ini. Pertanyaan tentang keadilan akses sarana dan layanan kesehatan mengemuka. Lebih lagi kalau kita melirik sektor kehidupan yang lain, seperti pendidikan, kebudayaan, dan pertanian misalnya, tragedi pandemi membuat potret kesenjangan dan ketidakadilan yang terjadi dalam kehidupan masyarakat kita menjadi lebih kasad mata. Karena itu pertanyaan-pertanyaan terkait dengan kesenjangan dan ketidakadilan tersebut melebar ke persoalan ekonomi yang lebih luas. Entah pertanyaan kritis tersebut terkait dengan arah pembangunan sistem ekonomi berkeadilan, kebijakan-kebijakan ekonomi yang telah diambil, serta tentang fondasi-fondasi ekonomi yang ada dan perlu terus dibangun selama ini. Diskusi seputar ekonomi kapitalis-liberal, komunis-sosialis, dan ekonomi Pancasila juga mengapung ke permukaan. ${ }^{1}$ Pertanyaan-pertanyaan kritis tersebut juga dipicu oleh adanya perubahan drastis dari pola konsumsi kehidupan masyarakat di era pandemi, yang mengubah peta struktur konsumsi, permintaan dan penawaran. Pertanyaan-pertanyaan terkait kecenderungan aliansi sistem ekonomi dan politik yang kita bangun sebagai sebuah bangsa yang mandiri juga muncul, kendati muatan politis gugatangugatan tersebut gampang diidentifikasi.

Intensifikasi krisis kehidupan tersebut juga kita temukan ketika kita menilik sisi kehidupan yang lain yakni kontestasi dan ketegangan antar kelompok masyarakat berdasar etnis, agama, atau identitas komunal yang lainnya. Krisis yang disuburkan oleh fenomena globalisasi dan perkembangan teknologi informasi dan komunikasi, yang mengekspose masyarakat kita kepada paham-paham budaya atau cara beragama baru, ideologi dan pandangan hidup yang berbeda, telah menciptakan fragmentasi kelompok sosial ketika kelompok-kelompok tersebut merespon secara berbeda aneka paham, ideologi, gaya hidup, dan pola berpikir baru tersebut berdasar "identitas" kultural atau religius atau ikatan komunal lain yang mereka yakini

1 Bdk. Jalan Penguatan Pasca Pandemi oleh Mohamad Ikhsan Modjo, Kompas, 18 Juni 2020. 
sebagai unsur substansial dari kelompok mereka. Krisis kesehatan dan ekonomi serta pembatasan ruang gerak dan interaksi, yang membuat beban kehidupan semakin berat, tanpa adanya celah-celah ruang katarsis, mempertajam potensi fragmentasi sosial entah karena perbedaan agama, etnis, atau klas sosial. Apalagi ketika potensi-potensi ketegangan fragmentasi sosial tersebut bertali temali dengan kepentingan atau permainan politik berbasis identitas. Dalam situasi semacam ini aneka nilai, pandangan, dan keyakinan yang selama ini menjadi referesi untuk membangun ikatan sosial kebangsaan seolah kurang revelan atau tidak memadai lagi.

Menurut hemat penulis, jika kita menilik secara mendalam dan cermat, aneka krisis yang mengemuka tadi sesungguhnya berakar pada sumber yang lebih dalam, yakni adanya krisis identitas, baik pada tataran individual, komunal, maupun pada tataran kehidupan berbangsa dan bernegara. Krisis identitas ini antara lain diintroduksi oleh fenomena globalisasi dan revolusi teknologi komunikasi dan informasi yang begitu dahsyat, yang telah menggoyahkan aneka pandangan, kesadaran, dan nilai-nilai tradisional tentang identitas dengan pandangan-pandangan dan pemahaman baru. Krisis identitas ini jugalah yang menyebabkan perdebatan tentang bagaimana membangun fondasi kehidupan berbangsa dan bernegara dan juga arah kemana bangsa dan negara ini harus melangkah tidak pernah kunjung usai. Untuk keluar dari krisis ini kategori-kategori tradisional tentang identitas tentu kurang memadai lagi. Karena itu pemahaman tradisional tersebut perlu disandingkan dengan kategori-kategori dan persepktif baru untuk memahami identitas. Kategori konstatatif tentang identitas sebagai ciri-ciri atau karakter yang sudah terinskripsi atau terberi (giveness) dari suatu entitas komunal hanya akan mengembangkan sikap-sikap defensif dan bahkan terjerumus ke sikapsikap fundamentalisme-regresif-eksklusif. ${ }^{2}$ Bertolak dari asumsi dan keprihatinan ini, penulis dalam artikel ini mengajukan usulan suatu perspektif baru dalam memahami identitas, yakni identitas sebagai proses produksi atau proses menjadi (in a making). Dalam perspektif ini, identitas diproduksi

2 Bdk. Ignatius Bambang Sugiharto, Problem Identitas dalam https://www.youtube.com/ watch $? v=Q u U s 6 p l A 9 E E \& p p=Q A A \% 3 D$. 
melalui tindakan-tindakan, pilihan-pilihan, dan cetusan-cetusan subjek dalam usahanya melestarikan dan mengembangkan hidupnya. Identitas merupakan proses mengukir (menginskripsi) unsur-unsur yang kemudian dianggap sebagai ciri-ciri dan karakter-karakter yang ajek dalam diri subjek dalam melestarikan dan mengembangkan hidupnya. Menurut penulis, perspektif identitas progresif inilah yang akan bisa menjadi titik pijak yang memungkinkan kita sebagai bangsa untuk mampu mencari jalan keluar dan solusi-solusi yang produktif di tengah-tengah krisis identitas tersebut. Dalam mengerjakan karya ini penulis menggunakan lensa kajian poskolonial untuk membaca realitas yang terjadi di Indonesia, dan dalam mengusulkan kemungkinan-kemungkinan yang bisa dilakukan untuk keluar dari krisis yang kompleks ini, yang antara lain adalah mengikis residu-residu kolonialisme. Karena itu kategori-kategori identitas, residu kolonialisme, mimikri, kontestasinegosiasi, akan muncul di sana-sini.

\section{Residu Kolonialisme}

Bulan Agustus 2020 ini, bangsa Indonesia merayakan genap 75 tahun kemerdekaannya. Sebuah perjalanan yang cukup panjang dari sebuah bangsa yang sebelumnya selama sekitar 350 tahun lebih pernah dikuasai oleh penjajah. Penjajahan adalah sebuah dominasi total dan kekerasan sistematis mencakup semua unsur kehidupan sebagai komunitas manusia, utamanya dalam segi ekonomi, sosial-budaya, dan politik. ${ }^{3}$ Resdidu dari proses kolonialisme yang begitu lama, tentu tidak mudah dihapuskan begitu saja, apalagi melalui proses-proses yang didesain secara sistematis hanya selama 75 tahun. Kita bisa mencermati bahwa residu-residu kolonialisme tersebut masih bercokol hingga kini dalam berbagai tataran kehidupan, dan mengemuka dalam berbagai wajah.

Dalam tataran kehidupan ekonomi kita bisa menemukan residu kolonialisme tersebut. Peta aktivitas ekonomi yang ada sekarang tidak jauh beranjak dari peta aktivitas ekonomi di masa kolonial. Aktivitas ekonomi yang hingga dewasa ini masih terkonsentrasi di kota kota di Jawa seperti

3 'Jean-Paul Sartre, Colonialism and Neocolonialism (London: Routledge, 2001), 30-47. 
Jakarta, Bandung, Semarang, Yogyakarta, Surabaya, dan Malang hanyalah sekedar perpetuasi aktivitas dan jalur ekonomi yang dulu berkembang di era kolonial. Demikian juga beberapa pusat aktivitas ekonomi di luar Jawa seperti di Aceh, Medan, Pontianak, Menado, Ende, yang umumnya sekaligus merupakan pusat-pusat pemerintahan di tingkat daerah, juga merupakan kelanjutan dari sentra-sentra ekonomi dan pemerintahan di era kolonial. Selain itu kecenderungan untuk mengekspor bahan-bahan mentah dari aneka kekayaan alam yang ada di Indonesia, lemahnya transfer teknologi, dan lemahnya struktur dan infrastruktur ekonomi yang mendukung produksi dan ekspor barang-barang jadi, merupakan cerminan bahwa aktivitas ekonomi bangsa Indonesia masih sekedar mendaur ulang (mimikri) sistem perdagangan di era kolonial. Dalam wilayah ini cita-cita untuk membangun ekonomi nasional yang berdikari, idealisme untuk menata sistem ekonomi berorientasi kerakyatan bisa dikatakan masih jauh panggang dari api. Alihalih membangun dengan mantab sistem ekonomi kerakyatan (Pancasila), selama perjalanan bangsa ini, kita cenderung terseret atau malah ditelan oleh sistem ekonomi kapitalis-liberal yang memang menjadi panglima di kancah perekonomian global. Dengan kata lain cita-cita untuk membangun struktur ekonomi yang sesuai dengan cita-cita atau idealisme sebuah bangsa yang bekepribadian masih jauh dari memuaskan. Cita-cita atau bahkan jargon ekonomi Pancasila (kerakyatan-keadilan) masih perlu diterjemahkan dalam penataan struktur ekonomi tertentu.

Dalam tataran kehidupan sosial dan budaya residu kolonialisme juga masih sangat bisa kita jumpai. Kampanye dan aneka program dan strategi untuk mencintai dan menggembangkan kebudayaan nasional, sepertinya tergeser oleh gelombang pengaruh kebudayaan dari luar negeri, utamanya kebudayaan barat (Amerika dan Eropa), dan juga kebudayaan dan teknologi dari negara-negara tetangga yang dipandang lebih maju seperti Korea, Cina, Jepang, dan India. Kenyataan ini menunjukkan bahwa banyak orang Indonesia masih cenderung berorientasi pada budaya (dan teknologi) yang dipandang lebih baik dan berkembang di negara-negara di luar Indonesia. Mentalitas "inlander" ini kita warisi dari generasi-generasi yang hidup dalam masa penjajahan. Dengan sendirinya mereka berkiblat pada negara-negara yang dianggap sudah lebih maju. Jika kita menengok lebih jauh, mentalitas 
feodal juga masih tersembunyi di sana sini di hampir semua tingkat strata kehidupan sosial di masyarakat kita. Juga mentalitas para pejabat negara yang hanya menuntut fasilitas, previlese, dan penghormatan. Sikap masyarakat kelas bawah yang menempatkan dirinya sebagai abdi dari mereka-mereka yang seharusnya menjadi pelayan masyarakat adalah juga cetusan mentalitas feodal. Memang struktur masyarakat dan budaya feodal sudah ada jauh sebelum datangnya kolonialisme, namun demikin menurut studi, kolonialisme justru memperkuat budaya feodal ini. Karena itu bisa dipahami masih dibutuhkan waktu yang panjang untuk mengembangkan struktur masyarakat dan budaya egalitarian, yang bisa mendukung sistem politik demkorasi sebagaimana dicita-citakan. Sistem demokrasi mengandaikan adanya dukungan dari struktur dan budaya masyarakat yang lebih egaliter.

Residu kolonial dalam bidang sosial dan budaya tersebut masih tetap bisa dijumpai di sana sini, juga disebabkan oleh pemahaman akan konsep tentang identitas budaya nasional yang masih belum dirumuskan secara jelas beserta tiadanya cetak biru untuk mewujudkan apa yang dipahami sebagai budaya ataupun identitas nasional. Sejauh penulis cermati, wacana tentang budaya nasional sering merujuk pada kumpulan warisan budaya-budaya lokal, yang nota bene didominasi oleh budaya jawa, dan beberapa budaya yang cukup dominan di wilayah lainya (Batak, Sunda, Madura). ${ }^{4}$ Karena itu disposisi yang biasa diambil oleh bangsa ini adalah mempertahankan warisanwarisan budaya tradisional yang dipandang sebagai identitas budaya nasional. Lagi-lagi sikap defensif-konservatif ini mengandaikan adanya pemahaman identitas sebagai ciri yang sudah terpatri dalam warisan budaya bangsa Indonesia dan suatu warisan yang harus dipertahankan. Identitas kulural dipahami sebagai kata benda (statis), bukan kata kerja.

Selain itu, residu kolonialisme juga bisa kita jumpai dalam tataran kehidupan politik. Hal pertama yang langsung bisa dilihat adalah bahwa kategori-kategori politis dan struktur atau sistem politik yang masih dominan

4 Bdk. Benedict R. O'G. Anderson, Languge and Power: Exploring Political Culture in Indonesia (Ithaca: Cornel University Press, 1990) 123-151. 
dalam kehiduan bernegara merupakan proses mimikri dari ketegori-kategori dan struktur yang diadopsi dari negara-negara penjajah. Konsep tentang negara, konstitusi, kekuasaan (power), produk hukum, beserta struktur yang dimiliki sebenarnya merupakan hal-hal yang diambil dari tatanan politik negara modern (barat). ${ }^{5}$ Namun kategori-kategori itu di sana-sini juga bernuansa paham-paham lokal. Ambivalesnsi ini tampak misalnya dalam pemahaman tentang kekuasaan. Di satu pihak menggunakan konsep barat, tetapi di lain pihak juga masih dimaknai dengan pemahaman-pemahaman lokal yang bernuansa feodalistik. Selain itu kategori-kategori yang digunakan untuk mengidentifikasi kelompok sosial yang berbeda juga tidak beranjak jauh dari kategori-kategori kolonial. Pribumi-non pribumi, ketegori komunitas sosial berdasarkan agama, suku maupun asal usul kebangsaan, ketegoriketegori yang menyebabkan terbentuknya tembok-tembok segregasi sosial tersebut sebenarnya merupakan perpetuasi dari apa yang dilakukan pemerintah kolonial dalam mengkategorikan unit-unit sosial dalam masyarakat, sedemikian rupa sehingga mereka tetap dikuasi oleh penguasa baru dengan strategi devide et impera mereka. Ketegori-kategori yang mencipta segregasi sosial inilah yang terus dipelihara oleh pelaku-pelaku politik identitas untuk mewujudkan kepentingan mereka. Karenanya ciriciri identitas konstatatif, terberi, selalu digaris bawahi dengan dalih purifikasi identitas yang eksklusif. Seraya mensubordinasi kelompok-kelompok identitas yang lain. Realitas sosial menjadi medan kontastasi terus menerus, bukan menjadi arena dialog, negosiasi, dan kolaborasi.

Sementara perjuangan untuk mengembangkan sistem dan budaya politik yang berakar pada apa yang diyakini sebagai nilai-nilai kebudayaan nasional belum menunjukkan hasil yang mantab dan stabil, akhir-akhir ini arena politik sangat diwarnai oleh permainan politik identitas, yang karena menerima limbah gerakan politik identitas berbasis agama dari negara-negara di Timur Tengah, artikulasi politik identitas keagamaan mengemuka dan

5 Dalam karyanya, Rethinking Indonesia, Simon Philpott menyatakan bahwa kajian-kajian tentang politik di Indonesia sangat dipengaruhi oleh kategori-ketegori politik Barat, karena sumber-sumber yang bisa diakses tentang Indonesia dipresentasikan oleh para pemikir Barat, Eropa dan kemudian Amerika. Bdk Simon Philpott, Rethinking Indonesia (London: Macmillan Press Ltd, 2000), XIV. 
mengusung bahayanya sendiri. Partai politik sendiri yang semestinya berbasis pada nilai-nilai Pancasila juga tergoda di sana-sini untuk memainkan sentimen keagamaan yang ekslusif untuk mengembangkan wacana-wacan dan jargon politik yang dianggap mampu mengikat kesadaran emosinal masa. Lagilagi pemahaman tentang identitas yang mewarnai politik identitas di sini adalah identitas inskriptif-konstatatif karenanya cenderung mengetengahkan eksklusifitas kelompok.

\section{Pemahaman Baru Identitas}

Dalam uraian sebelumnya penulis menunjukkan bahwa aneka krisis yang menjadi begitu intens, menyusul krisis kesehatan dan ekonomi di masa pandemi, antara lain disuburkan oleh residu-residu kolonial yang tak kunjung usai dikelola dengan baik. Residu tersebut bisa disimak dalam tataran ekonomi, sosial-budaya, dan politik. Patut dicatat pula bahwa selain residu kolonial, gelombang globalisasi dengan media digitalnya membuat negara kita harus menghadapi aneka arus tantangan yang begitu berat dan kompleks, tanpa preseden sebelumnya. Globalisasi dan digitalisasi media komunikasi dan informasi sungguh-sungguh mengekspose masyarakat kita pada pahampaham, nilai-nilai dan bahkan ideologi-ideeologi baru. Karena itu pertanyaanpertanyaan seputar identitas, baik dalam tataran individual, komunal, maupun sebagai bangsa mengemuka. Persoalan menjadi semakin rumit ketika gagasan-gagasan tentang identitas atau konsep tentang manusia Indonesia, dan bahkan karakter bangsa Indonesia, belum menemukan referensi yang meyakinkan. Jargon-jargon tentang gambaran manusia Indonesia, identitas kolektif sebagai bangsa memang tidak didasari oleh telaah filosofis yang mendalam dan komprehensif. Malahan yang muncul disana-sini hanyalah asumsi-asumsi yang berisi karakter-karakter konstatatif tentang manusia Indonesia, yang dianggap merupakan karakter-karakter bawaan yang diwarisi turun temurun oleh manusia-manusia yang lahir di bumi Indonesia. Ciri-ciri yang seringkali diidentifikasi sebagai kharakter khas manusia Indonesia adalah berbudi luhur, ramah tamah, sopan santun, bersemangat gotong royong. Semuanya merupakan ciri normatif yang dianggap selalu melekat dalam diri manusia Indonesia. Demikin juga dalam tataran komunal entah 
identitas kolektif dari berbagai etnik group, maupun identitas sebagai bangsa, identitas-identitas tersebut tidak didasarkan pada sebuah pemikiran-pemikiran filosofis yang koheren dan sistematis, tetapi sekedar muncul sebagai slogan atau jargon-jargon untuk membangkitkan identitas khas dari bangsa ini. Dan karakter-karakter yang dianggap melekat tersebut bersifat normatif, konstatatif, dan statis, seolah-olah dari generasi ke generasi terus begitu.

Di balik pemikiran-pemikiran semacam itu tersembunyi suatu pemahaman tentang "identitas" (karakter-karakter penanda) yg normatif, konstatatif, dan statis. Identitas merujuk hanya pada karakter-karakter yang diandaikan terus menerus diwariskan oleh generasi sebelumnya. Pemahaman identitas semacam ini cenderung konservatif, dan melihat identitas sebagai ciri-ciri yang terberi-terinskripsi, bukan sebuah proses produksi. Mengingat identitas semacam ini tidak didasarkan pada suatu pemikiran filosofis yang komprehensif dan mendasar, tetapi lebih menunjuk pada atribut-atribut yang diasumsikan diwarisi turun temurun, maka bisa dikatakan pemahaham identitas semacam ini "groundless". Karena itu wacana yang berkembang adalah usaha-usaha konservatif (to conserve), defensif, dan eksklusif dengan label mempertahankan identitas dari pengaruh-pengaruh yang berasal dari kebaruan dan dunia di luar diri mereka. Sementara apa yang diandaikan diwariskan terus menerus dari generasi ke generasi, dalam perjalanan waktu mengalami proses keterputusan (diskontinuitas), karena dianggap tidak relevan atau tidak mampu mengikat secara afektif minat dari generasi yang lebih muda untuk melestarikan dan menghidupi warisan-warisan identitas tersebut.

Berangkat dari kondisi-kondisi semacam itu maka penulis berpendapat bahwa, salah satu cara yang bisa dilakukan dalam mengelola dan mengatasi krisis yang terjadi adalah memugar pemahaman tentang identitas, dengan suatu gagasan baru yang telah diartikulakisan oleh para pemikir Poskolonialsime dan Kajian Budaya, yakni dengan memahami identitas sebagai proses produksi dan proses menjadi. Apa yang diinskripsi terus menerus melalaui tindakan-tindakan, keputusan-keputusan dan pilihan-pilihan yang dilakukan oleh subjek, itulah yang akan memproduksi identitas seseorang atau sebuah komunitas sosial, atau bahkan sebuah bangsa. Gagasan ini memahami identitas sebagai suatu proses berkelanjutan dari 
subjek konkret, berorientasi ke masa depan atau cita-cita bersama sebuah komunitas, dan terbuka terhadap kemungkinan-kemungkinan dan pemahaman-pemahaman baru yang dijumpai subjek.

Dalam sebuah wawancara yang dilakukan Julie Drew, dari Universitas Akron, salah satu pemikir Kajian Budaya sekaligus Poskolonial, Stuart Hall menjelaskan usulannya untuk memahami identitas secara baru. Stuart Hall mengklarifikasi demikian:

It's the notion that identity is always in the making. There is one idea of identity as a fixed position, and another idea that identity is relative to the extreme. There is now a third position in that debate because I think those people have moved away from identity as process and have sometimes gone right over the point where identity is nothing at all; it's a kind of open field where one just sort of occupies a particular identity out of habit. So it is that there's no fixed identity, but it's not that there's just an open-ended horizon where we can just intentionally choose. ${ }^{6}$

Ungkapan tersebut menegaskan bahwa identitas adalah suatu proses menjadi, dan bukan serangkaian karakter atau atribut yang sudah final yang dianggap melekat dalam diri subjek. Senada dengan Stuart Hall, Edward Said dalam Humanism and Democratic Criticism juga menegaskan bahwa identitas merupakan suatu tindakan berkelanjutan, atau apa yang dia sebut sebagai "an ongoing practice." Serangkaian tindakan, pilihan-pilihan dalam merespon segala sesuatu yang hadir dalam subjek, aneka bentuk artikulasi diri mengukir apa yang dipahami sebagai identitas. Dengan demikian identitas adalah suatu proses menjadi, suatu keterbukaan dan sikap-tindakan yang diorientasikan ke masa depan (in a making). Identitas bukanlah karakter-karakter yang dideduksikan dari sebuah teori filosofis tertentu, atau konsep-konsep essensialistis dan bersifat sudah jadi-final (fixed), yang darinya dideduksikan prinsip-prinsip etis/moral yang harus menjadi referensi bagi kehidupan subjek. Dengan kata lain identitas merupakan proses menjadi,

6 Gary A. Olson and Lynn Worsham (ed.), Race, Rhetoric, and the Postcolonial (New York: State University of New York Press, 1999), 207.

7 Edward W. Said, Humanism and Democratic Criticism (New York: Columbia University Press, 2004), 6. 
suatu proses yang diproduksi terus menerus melalui serangkaian tindakan, pilihan-pilihan keseharian, dan aneka cetusan yang diekspresikan dalam merespon situasi, tantangan, paham-paham yang dijumpai subjek, dalam rangka melestarikan eksistensinya (self-preservation) dan mengembangkan dirinya. Dalam perspektif baru yang dinamis ini, etika, atau moralitas, atau tuntunan kehidupan, bukanlah serangkaian norma atau hukum-hukum yang dideduksi dari suatu konsep antropologi metafisis tertentu atau teori filosofis yang sistematis, tetapi sesuatu yang mengalir dari daya hidup (elan vital) dalam diri subjek yang mengarahkan subjek dalam melestarikan hidup dan mengembangkan dirinya.

Menurut hemat penulis, di tengah-tengah absennya pemikiran filosofis yang koheren, mendalam, dan sistematis tentang hakikat manusia Indonesia, tentang refleksi hakikat komunitas-komunitas etnik dan suku, serta tentang identitas (budaya) nasional Indonesia, yang dari pemikiran-pemikiran filosofis tersebut seharusnya dideduksi sistem moral (dan hukum) yang bisa menjadi rujukan entah dalam tataran individu, kelompok sosial, maupun sebagai bangsa, maka pemahaman baru tentang identitas sebagai proses produksi yang lebih inklusif kiranya menjadi sangat relevan dan punya alasan yang mendasar. Menurut studi penulis sebelumnya, suatu refleksi filosofis yang sistematis dan koheren tentang gagasan manusia Indonesia memang belum pernah dilakukan. ${ }^{8}$ Ambil contoh misalnya studi Mochtar Lubis, dia hanya menengarai beberapa karakter manusia Indonesia, antara lain hipokrit, segan dan enggan bertanggungjawab, berjiwa feodal, percaya pada takhayul, artistik, dan berwatak/karakter lemah. ${ }^{9}$ Ciri-ciri tersebut bagi penulis belum merupakan sebuah refleksi filosofis yang komprehensif tentang identitas manusia Indonesia. Demikian juga dalam tataran kehidupan komunal, entah sebagai kelompok etnik atau kategori komunal yang lain, tidak pernah ditemukan suatu kajian filosofis yang komprehensif yang dianggap sebagai ciri-ciri essensial dari identitas komunal tertentu. Terlebih dari kajian penulis, sejak wacana tentang identitas nasional dan nasionalisme Indonesia

\footnotetext{
8 Robertus Wijanarko, Exploring Indonesian Humanism (Chicago: DePaul University, 2007), 114-131.

9 Mochtar Lubis, Manusia Indonesia (Jakarta: Yayasan Pustaka Obor, 2013).
} 
mengemuka, belum ada suatu studi filosofis yang sistematis dan komprehensif tentang apa yang sebenarnya dipahami sebagai identitas nasional atau bahkan budaya nasional. Apa yang dipahami sebagai budaya nasional sering kali hanya merujuk pada kumpulan dari budaya-budaya lokal (etnik), yang harus dipelihara (konservatif) dan dipertahankan (eksklusifdefensif), serta diletakkan berhadapan dengan budaya-budaya asing yang dianggap sebagai musuh.

Ketika suatu refleksi filosofis yang sistematis dan koheren tentang identitas manusia, identitas komunal, dan identitas sebagai bangsa tidak ditemukan, dan kita memahami identitas sebagai proses produksi atau proses menjadi, lalu apakah yang bisa menjadi rujukan atau tuntunan, yang bisa menjadi payung atau panduan kehidupan pada tataran kehidupan individu, kelompok etnik atau bangsa, dalam menjalani kehidupan ke depan? Apa yang bisa menjadi pegangan ketika kita harus memfilter pengaruh-pengaruh, budaya, ideologi, atau paham-paham baru yang kita anggap tidak berasal dari kebudayaan lokal? Apakah kita hidup mengalir begitu saja, tanpa adanya norma-norma dan orientasi, baik sebagai entitas individu ataupun entitas komunal, ibarat sebuah kapal melaju tanpa kompas atau panduan? Sebagai bangsa, yang didalamnya terdapat kelompok-kelompok sosial yang beragam, bagaimana kontestasi dan konflik antar kelompok etnis atau agama, yang seringkali diperburuk oleh permainan politik identitas, itu bisa diubah menjadi suatu proses negosiasi, dialog, kohabitasi produktif yang berkesinambungan, sehingga cita-cita bersama sebuah bangsa bisa diwujudkan? Pertanyaan-pertanyaan tersebut beralasan karena, selama ini potensi konflik etnik dan agama sebagaimana penulis indikasikan di awal tulisan ini misalnya, direspon dengan cara represif yakni dengan mengimposisi nilai-nilai, aturan-aturan, dan hukum tanpa mengelola kontestasi dan konflik menjadi proses dialog dan negosiasi yang saling memurnikan dan mengembangkan.

\section{Pijakan Bersama Menuju Identitas Inklusif}

Untuk menjawab pertanyaan-pertanyaan mendasar terkait dengan konsekuensi etis dari gagasan identitas sebagai produk tersebut penulis 
mengajukan pemikiran yang menurut hemat penulis layak untuk diperhatikan dalam mengembangkan pemahaman identitas sebagai proses produksi, identitas sebagai proses menjadi, dan bersifat inklusif. Dalam konteks manusia Indonesia, penulis berangkat dari kenyataan manusia Indonesia sebagai makhluk eksistensial dan menyejarah, beranjak ke tinjauan manusia Indonesia dalam tataran individual dan komunal, dan akhirnya dalam tataran kehidupan sebagai sebuah bangsa yang sekaligus bagian dari bangsa di dunia (universal).

Pertama, penulis bertolak dari kenyataan manusia Indonesia sebagai makhluk eksistensial yang menyejarah. Bukanlah kebetulan atau sebuah ke-alpa-an ketika kita menjumpai bahwa dalam konteks Indonesia kita tidak menemukan gagasan filsafat antropologi yang sistematis dan komprehensif. Penulis menengarai sekurang-kurangnya ada dua alasan mendasar yang menyebabkan absennya filsafat antropologi ini. Alasan pertama adalah kenyataan akan pluralitas masyarakat di Indonesia. Pluralitas etnik atau suku atau kelompok sosial yang ada di Indonesia mengisyaratkan akan adanya warisan tradisi pemikiran dan budaya yang beragam. Setiap suku bisa diandaikan mempunyai mitos, kosmogoni, kosmologi, dan tentu saja pemahaman tentang hal-hal yang hakiki tentang manusia yang berbeda. Dengan sendirinya, kenyataan ini berujung pada pemahaman yang berbeda tentang ciri-ciri hakiki dari manusia sesuai dengan tradisi pemikiran dan budaya yang berbeda-beda tersebut. Merujuk pada realitas semacam ini, tentu tidak mudah untuk merumuskan gagasan yang mendasar, sistematis, komprehensif, dan berlaku umum tentang manusia Indonesia. Kedua, berbeda dengan tradisi pemikiran barat (kontinental), dalam tradisi pemikiran filsafat di Indonesia kita tidak mempunyai kerangka epistemologis yang dalam sejarah tradisi pemikiran barat telah melahirkan kategori-ketergori metafisis tentang manusia sebagai subjek, yang diklaim bersifat universal. Apa yang kita jumpai dalam tradisi pemikiran Indonesia adalah usaha-usaha untuk menemukan ciri-cici pokok atau karakter-karater mendasar yang dianggap sebagai sesuatu yang diwarisi oleh manusia Indonesia dan perlu terus dilestarikan.

Namun demikian biarpun teori filosofis komprehensif tentang Indonesia tidak dirumuskan, kita tetap bisa menggarisbawahai fakta hakiki dari 
manusia Indonesia, yakni sebagai insan-insan yang eksis dan menyejarah. Mereka adalah makhluk yang ada, hidup dan menyejarah (hidup dalam sejarah). Tiap individu dituntun sekurang-kurangnya oleh dua hal, yakni daya dorong naluriah untuk hidup (survival) dan mengembangkan diri, serta aneka pra pemahaman yang diterimanya sebagai makhluk yang lahir dan tumbuh dalam tradisi budaya dan agama tertentu dengan unsur-unsur yang terkandung di dalamnya. Dengan demikian di satu pihak dia dikondisikan oleh konteks sejarahnya, tetapi, di lain pihak, konteks historis (kultural dan religius) itu tetap memberi ruang untuk mentrandensi diri, bergerak dan mendobrak tradisi itu, karena daya dorong naluriah (elan vital) untuk mempertahankan hidup dan mengembangkan dirinya. Mereka adalah insan-insan yang tidak semata ditawan oleh tradisi budaya dan agama atau dibebani tanggung jawab untuk membabi buta mempertahankan (to defend) warisan-warisan tradisi budaya dan agamanya, tetapi individu-individu yang mampu mentransformasi unsur-unsur historis tersebut untuk kehidupan yang lebih baik dan mengembangkan. Dengan demikian melalui proses-proses mentransformasi sejarah dan budaya yang diwarisinya, manusia Indonesia memproduksi identitas dirinya. Mereka mengukir identitas dirinya melalui serangkain tindakan, pilihan-pilihan, dan cetusan-cetusan hidup, dengan tetap berpijak pada tradisi yang masih bisa diadaptasikan, untuk melestarikan dan mengembangkan hidupnya. Mereka bukanlah peziarah-peziarah yang sekedar mengembara tanpa panduan dan tujuan, tetapi pribadi-pribadi yang bergerak maju dengan tujun dan panduan-panduan sejauh diperlukan untuk mengejar tujuan dan mengembangkan hidupnya. Pemahaman semacam ini mengembangkan sikap individu-individu yang terbuka, akomodatif, dan dialogis-inklusif terhadap unsur-unsur berbeda dan baru yang dijumpainya.

Kedua, manusia Indonesia sebagai individu dan bagian dari komunitas dimana dia dimiliki. Selain hadir sebagai subjek yang berpikir dan merasa, Individu-individu yang hidup di bumi Indonesia adalah sekaligus menjadi bagian dari entitas komunalnya, entah dalam artian etnis, suku atau entitas religius, yang karenanya menjadi bagian dari komunitas religius atau kultural tertentu. Sebagai Individu, setiap manusia Indonesia tidak harus terjebak dalam pemahaman dirinya sebagai subjek yang sudah jadi, dengan karakter yang sudah diperskripsi secara final, dan karenanya harus bersikap eksklusif- 
defensif mempertahankan identitas tersebut. Sebaliknya, dengan pemahaman identitas sebagai proses produksi (menjadi), setiap individu menyadari bahwa dia harus berko-eksistensi dengan individu-individu yang lain (liyan). Karena itu sikap kolaboratif, dan bukan subordinatiflah, yang akan mengembangkan dirinya. Orang lain tidak seharusnya ditundukkan (subordinasi) sekedar menjadi objek keinginanya. ${ }^{10}$ Dengan kata lain pemahaman identitas sebagai produksi, sebagai proses menjadi, mengharuskan setiap individu berkoeksistensi dan berkohabitasi dengan sesamanya, karena itulah jalan untuk melestarikan dan mengembangkan hidupnya. Kerangka berpikir semacam ini tentu saja menyuguhkan suatu orientasi etis atau tuntunan bagi setiap individu dalam rangka mempertahankan dan mengembangkan hidupnya (self-preservation).

Selanjutnya, biarpun selalu sebagai anggota komunitas asalnya, setiap orang adalah individu yang mampu berpikir kritis, mengambil jarak terhadap nilai-nilai, pandangan, tradisi-tradisi komunitasnya. Dia adalah subjek yang mampu berpikir kritis, karenanya tidak pernah bisa ditelan atau direduksi semata-mata sebagai entitas komunal. Justru ketika sebuah komunitas sosial terdiri dari individu-individu yang mampu berpikir kritis, dan tidak direduksi semata-mata sebagai sebuah komponen dari entitas komunal, entitas komunal tersebut akan mampu berkembang menjadi komunitas yang sehat karena akan menjadi komunitas yang inklusif-dialogis, yang mampu terbuka dan berdialog dengan entitas-entitas komunal lain di luar dirinya. Pemahaman identitas sebagai proses produksi, dengan demikian, juga akan menyebabkan berkembangnya komunitas-komunitas sosial yang inklusif. Sebaliknya jika komunitas sosial terdiri dari orang-orang yang hanya tunduk dan secara konservatif melestarikan tradisi dan nilai komunitasnya, maka yang tumbuh adalah komunitas yang defensif-eksklusif, dan cenderung melihat entitas sosial yang lain sebagai ancaman dalam kontestasi, dan bahkan cenderung mensubordinasi komunitas-komunitas yang lain. Karena itulah pemahaman baru identitas sebagai proses produksi, sebagai proses menjadi, memberi tempat pada berkembangnya individu-individu yang melalui pemikiran

10 Bdk. Jane Hiddleston, Understanding Postcolonialism (Stocksfield-UK: Acumen, 2009), 15-23. 
kritisnya kemungkinan untuk mengukir identitasnya melalui tindakantindakan, pilihan-pilihan, cetusan-cetusan yang dihasilkan dari sikap terbuka, kritis, dan inklusif terhadap aneka kemungkinan baru yang dijumpainya. Selain itu, kenyataan bahwa mereka adalah individu-individu yang juga sekaligus anggota komunitas asalnya, juga memberi panduan untuk menyeleksi mana nilai-nilai yang masih bisa dilestarikan, dan mana nilainilai yang perlu ditransformasi. Tambahan lagi, komunitas-komunitas dimana mereka hidup dan menjadi bagian, juga menemukan panduan dan orientasi dalam melestarikan sekaligus mengembangkan dirinya dengan tetap berko-eksistensi dan berkolaborasi dengan komunitas-komunitas lain di luar dirinya.

Ketiga, dimensi universal dari manusia. Sama halnya dalam tinjauan manusia sebagai makhluk eksistensial yang menyejarah, dan manusia sebagai makhluk individu sekaligus makhluk komunal (sosial), dalam tinjauan manusia Indonesia sebagai bagian dari sebuah bangsa dan warga dunia, absennya refleksi filosofis yang sistematis dan koheren tentang identitas manusia Indonesia dan identitas nasional yang sudah jadi dan final, memberi ruang untuk pemahaman baru tentang identitas sebagai sebuah proses produksi dan proses menjadi. Gambaran tentang manusia Indonesia dan identitas bangsa Indonesia, tetaplah akan menjadi sebuah cita-cita yang hendak diwujudkan, dan bukan sebagai ciri-ciri final yang sudah diperskripsikan atau selalu melekat. Identitas manusia Indonesia dan keindonesiaan diukir melalui serangkaian tindakan, pilihan-pilihan, dan cetusan-cetusan dari bangsa Indonesia, juga ketika manusia dan bangsa Indonesia berjumpa dan bergaul dengan bangsa-bangsa lain di dunia ini, dalam mengukir identitas mereka. Perjumpaan dan pergaulan yang terbuka dan inklusif dengan bangsa-bangsa lain, akan semakin memungkinkan manusia dan bangsa Indonesia untuk mengukir identitas dirinya yang khas, dan sekaligus membantu untuk menemukan identitas terdalam dari eksistensinya. Sementara itu, kebutuhan untuk melestarikan (self-preservation) dan mengembangkan diri, baik dalam tataran individual, komunal, maupun sebagai bangsa, juga menuntut manusia dan bangsa Indonesia untuk menjaga kelestarian dan kebaikan kehidupan orang lain atau bangsa-bangsa lain. Setiap sikap defensif atau bahkan usahausaha agresif untuk mensubordinasi orang atau bangsa lain, pada giliranya 
akan membahayakan eksistensi diri sendiri atau usaha dari bangsa ini untuk melestarikan dan mengembangkan eksistensinya. Kesadaran sebagai manusia konkret dan bangsa, yang digerakkan untuk melestarikan dan mengembangkan dirinya, dan realitas historis, individual, dan komunal dari eksitensi manusia dan bangsa Indonesia, memberikan orientasi etis/normatif atau panduan bagi manusia dan bangsa Indonesia bagaimana melestarikan dan mengembangkan hidupnya di tengah-tengah bangsa-bangsa yang berbeda. Karena itu relasi yang terbuka, saling bernegosiasi, dan berkolaborasi dengan manusia atau bangsa-bangsa lain, merupakan tuntutan yang mengalir dari kesadaran bahwa manusia dan bangsa Indonesia adalah entitas yang terus menerus mengukir identitas dirinya.

\section{KEPUSTAKAAN}

Anderson, Benedict R. O'G. Language and Power: Exploring Political Cultures in Indonesia, Ithaca: Cornell University Press, 1990.

Hiddleston, Jane. Understanding Postcolonialism, Stocksfield-UK: Acumen, 2009.

Lubis, Mochtar. Manusia Indonesia, Jakarta: Yayasan Pustaka Obor, 2013.

Olson, Gary A. dan Lynn Worsham. Race Rethoric and The Postcolonial, New York: State University Press, 1999.

Philpott, Simon. Rethinking Indonesia: Postcolonial Theory, Authoritarianism and Identity, London: Machmillan Press Ltd: 2000.

Said, Edward W. Humanism and Democratic Criticism, New York: Columbia University Press, 2004.

Sartre, Jean-Paul. Colonialism and Neocolonialism, London: Routledge, 2001.

Wijanarko, Robertus. Exploring Indonesian Humanism, Chicago: DePaul University, 2007.

\section{Website, Koran/Jurnal}

Sugiharto, Ignatius Bambang. Problem Identitas, https://www.youtube. com/watch?v=QuUs6plA9EE. Kompas, 18 Juni2020. 